\title{
Assessment of the variability of Elymus caninus (Poaceae) and closely related taxa from Russia and Kazakhstan using ISSR markers
}

\author{
Elena Shabanova (Kobozeva) ${ }^{1 *}$, Maria Emtseva $^{1}$, Alexander Agafonov ${ }^{1}$, and Baorong Lu $^{2}$ \\ ${ }^{1}$ Central Siberian Botanical Garden SB RAS, Zolotodolinskaya st., 101, Novosibirsk, Russia, 630090 \\ ${ }^{2}$ Ministry of Education Key Laboratory for Biodiversity and Ecological Engineering, Fudan \\ University, Songhu Road 2005, Shanghai 200438, China
}

\begin{abstract}
A comparative study of taxa that are morphologically close to Elymus caninus, occurring in the territory of Russia and Kazakhstan, was carried out based on the ISSR molecular fingerprints. Data showed that the studied taxa are groups of individuals phylogenetically closely related to $E$. caninus. The assumption is confirmed that E. viridiglumis, as an Elymus species, has a polyphyletic origin as a part of microevolutionary processes in populations E. caninus s. 1., possibly involving E. mutabilis. For the Caucasian endemic E. prokudinii and Kazakhstan endemic E. goloskokovii, the origin as result of introgression or spontaneous mutagenesis, i.e. a manifestation of the natural intraspecific polymorphism of E. caninus, is also assumed.
\end{abstract}

\section{Introduction}

In our opinion, confirmed species of the genus Elymus L., growing on Russian area [1], can be divided into several groups. Two of them are most important in terms of systematics and taxonomy:

1. Species with normal seed reproduction, having confirmed distribution area and abundance. This group should include close in origin, but independent species E. caninus (L.) L., E. mutabilis (Drob.) Tzvel. and E. fibrosus (Schrenk) Tzvel.

2. Species, representing morphologically deviating forms (MDF) of the basic species from the first group. Species from this group may have polyphyletic origin.

The study of number of species protologues, described from Russian area, and morphological analysis of grown specimens allowed to detect species, close to the ones from the first group. So, Elymus viridiglumis (Nevski) Czer. and E. prokudinii (Sered.) Tzvel. were described from the Southern Ural as a Roegneria viridiglumis Nevski [2], and the second one from the North Caucasus - as a Roegneria prokudinii Seredin [3]. The series of differences in description of diagnostic traits between protologues of these species and later identification keys, which were suggested by N.N. Tzvelev, gave reason to subject these taxa to E. uralensis as subspecies $[4,5]$.

\footnotetext{
* Corresponding author: ekobozeva87@mail.ru
} 
Elymus viridiglumis and E. prokudinii are morphologically similar, and we consider that they are derived from E. caninus, and possibly with participation of E. mutabilis.

Another species with probable relationship and even origination from E. caninus may be E. goloskokovii Kotuch., described from the North Kazakhstan, West Altai [6]. The origination of this species from E. fibrosus and E. trachycaulus (Link) Gould ex Shinners, supposed by author, seems to be based only on similarity in the trait of short lemma awns (1.5-4 mm), unlike the typical E. caninus forms (15-20 mm).

We consider appropriate to include accessions of mentioned species in comparative research with the use of a set of experimental methods. This report presents data on polymorphism and specificity of intermicrosatellite DNA sequences (ISSR-markers) to evaluate relationships between different Elymus morphotypes from locations within Russian Federation and adjacent Kazakhstan areas.

\section{Materials and Methods}

The list of accessions and their locations are given in Table 1. The following marker traits were identified: pilose surfaces of lemmas (in E. viridiglumis and E. prokudinii) and shortened lemma awns (in E. goloskokovii). Morphological peculiarity of Caucasian accessions (MDF) OSE-1427 and PTI-1837 is presented by short prickly (in contrast to long pilose) rachillas, and MDF AKL-0703 is characterized by densely pilose lemmas, but at the time by glabrous leaf blades (LB) unlike E. viridiglumis with pilose LB. All procedures of ISSR analysis were carried out as described previously [7].

Table 1. Locations of E. caninus accessions and related taxa taken in ISSR analysis. The numbering corresponds to ISSR patterns.

\begin{tabular}{|c|c|c|}
\hline № & $\begin{array}{c}\text { Taxon } \\
\text { Accession code }\end{array}$ & Location of collecting \\
\hline \multicolumn{3}{|c|}{ The Republic of Kazakhstan } \\
\hline 1 & E. caninus KZA-1706 & $\begin{array}{l}\text { Vicinity of Besqaynar town, alt. } 1665 \mathrm{~m} \mathrm{~N} 43^{\circ} 12.161^{\prime} \\
\text { E } 77^{\circ} 6.922^{\prime}\end{array}$ \\
\hline 2 & E. caninus EK-1716 & $\begin{array}{l}\text { Vicinity of Shingistay village, alt. } 915 \mathrm{~m} \mathrm{~N} 49^{\circ} 11.488^{\prime} \\
\text { E } 86^{\circ} 01.621^{\prime}\end{array}$ \\
\hline 3 & E. viridiglumis EK-1418 & $\begin{array}{l}\text { Vicinity of Berezovka village, alt. } 1202 \mathrm{~m} \mathrm{~N} 50^{\circ} 07.623^{\prime} \\
\text { E } 83^{\circ} 49.210^{\prime}\end{array}$ \\
\hline 4 & E. goloskokovii EK-1513 & $\begin{array}{l}\text { Vicinity of Poperechnoye village, alt. } 1202 \mathrm{~m} \mathrm{~N} \\
50^{\circ} 21.128^{\prime} \text { E } 83^{\circ} 53.527\end{array}$ \\
\hline \multicolumn{3}{|r|}{ Siberia } \\
\hline 6 & E. goloskokovii TUV-9936 & $\begin{array}{l}\text { The Tyva Republic, Todzhinsky District, valley of Bii- } \\
\text { Khem river }\end{array}$ \\
\hline 7 & E. viridiglumis SON-9904 & $\begin{array}{l}\text { The Republic of Khakassia, floodplain of the Ona river, } \\
\text { alt. } 713 \mathrm{~m}, \mathrm{~N} 52^{\circ} 10.772^{\prime} \mathrm{E} 89^{\circ} 51.907 \text { ' }\end{array}$ \\
\hline 8 & E. caninus KRG-1601 & $\begin{array}{l}\text { Krasnoyarsk Krai, alt. } 213 \text { m, N } 58^{\circ} 26.294^{\prime} \text { E } 98^{\circ} \\
33.358^{\prime}\end{array}$ \\
\hline 9 & E. caninus МОФ AKL-0703 & Altai Krai, alt. 98 m, N 5255.19’ E 7946.22’ \\
\hline 11 & E. viridiglumis BEL-1404 & 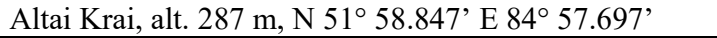 \\
\hline \multicolumn{3}{|c|}{ The Republic of Bashkortostan, Southern Ural, vicinity of settl. Novoabzakovo } \\
\hline 12 & E. caninus ABZ-1654 & alt. $616 \mathrm{~m}, \mathrm{~N} 53^{\circ} 48.250^{\prime} \mathrm{E} 58^{\circ} 36.846^{\prime}$ \\
\hline 13 & E. caninus UKU-1613 & alt. $561 \mathrm{~m} \mathrm{~N} 53^{\circ} 48.740^{\prime} \mathrm{E} 58^{\circ} 39.560^{\prime}$ \\
\hline 14 & E. viridiglumis $\mathrm{ABZ}-1637$ & alt. $616 \mathrm{~m}, \mathrm{~N} 53^{\circ} 48.250^{\prime}$ E $58^{\circ} 36.846^{\prime}$ \\
\hline 15 & E. viridiglumis UKU-1618 & alt. $619 \mathrm{~m} \mathrm{~N} 53^{\circ} 48.718^{\prime}$ E $58^{\circ} 40.377^{\prime}$ \\
\hline 16 & E. mutabilis ABZ-1607 & alt. $546 \mathrm{~m}, \mathrm{~N} 53^{\circ} 47.845^{\prime}$ E $58^{\circ} 37.291^{\prime}$ \\
\hline 17 & E. fibrosus ABZ-1602 & alt. $546 \mathrm{~m}, \mathrm{~N} 53^{\circ} 47.845^{\prime}$ E $58^{\circ} 37.291^{\prime}$ \\
\hline
\end{tabular}




\begin{tabular}{|c|c|c|}
\hline \multicolumn{3}{|c|}{ Caucasus, The Republic of North Ossetia - Alania } \\
\hline 18 & E. caninus OSE-1423 & $\begin{array}{l}\text { Valley of Tseydon river, alt. } 1951 \mathrm{~m}, \mathrm{~N} 42^{\circ} 47.139^{\prime} \mathrm{E} \\
43^{\circ} 53.605^{\prime}\end{array}$ \\
\hline 19 & E. caninus МОФ OSE-1427 & $\begin{array}{l}\text { Valley of Urukh river, alt. } 1996 \mathrm{~m}, \mathrm{~N} 42^{\circ} 52.898^{\prime} \mathrm{E} 43^{\circ} \\
35.959^{\prime}\end{array}$ \\
\hline 21 & E. caninus OSE-1429 & $\begin{array}{l}\text { Valley of Urukh river, alt. } 1829 \mathrm{~m} \mathrm{~N} 42^{\circ} 54.175^{\prime} \mathrm{E} 43^{\circ} \\
35.626^{\prime}\end{array}$ \\
\hline \multicolumn{3}{|c|}{ Caucasus, The Karachay-Cherkess Republic } \\
\hline 22 & E. caninus TEB-1811 & $\begin{array}{l}\text { Mount Malaya Khatipara, alt. } 2020 \mathrm{~m} \mathrm{~N} 43^{\circ} 26.508^{\prime} \mathrm{E} \\
41^{\circ} 42.693 \text { ' }\end{array}$ \\
\hline 23 & E. caninus МОФ РТІ-1837 & $\begin{array}{l}\text { Valley of Dombai-Ulgen river, alt. } 1990 \mathrm{~m} \mathrm{~N} 43^{\circ} \\
15.779^{\prime} \mathrm{E} 41^{\circ} 41.349^{\prime}\end{array}$ \\
\hline 24 & E. prokudinii TEB-1806 & $\begin{array}{l}\text { Mount Malaya Khatipara, alt. } 2020 \mathrm{~m} \mathrm{~N} 43^{\circ} 26.508^{\prime} \mathrm{E} \\
41^{\circ} 42.693 \text {, }\end{array}$ \\
\hline \multicolumn{3}{|r|}{$F_{1}$ hybrids } \\
\hline 5 & \\
\hline 10 & \multirow{2}{*}{\multicolumn{2}{|c|}{$\begin{array}{l}\text { E. caninus MDF AKL- } 0703 \times \text { E. prokudinii } \text { TEB- } 1806 \\
\text { E. caninus MDF OSE } 1427 \times \text { E. prokudinii } \mathrm{TEB}-1806\end{array}$}} \\
\hline 20 & & \\
\hline
\end{tabular}

\section{Results and Discussions}

High polymorphism (92-100\%) of intermicrosatellite DNA sequences in 24 accessions of studied species was revealed when comparing ISSR-profiles, obtained with 5 primers (17899B, HB12, M11, M2 (shown in Fig. 1 by increasing variability) and UBC-808) (Fig. 1 , Table 2). ISSR-fragments (119) varied in the range from $\sim 300$ to $2000 \mathrm{bp}$. The largest number of bands (28) was obtained when using an M2 primer. The least variable profiles were received with $17899 \mathrm{~B}$ primer -15 bands.

Table 2. Characteristic of primers, used for the study of ISSR-variability.

\begin{tabular}{|l|l|l|l|l|l|l|}
\hline $\begin{array}{l}\text { Name } \\
\text { of primer }\end{array}$ & $\begin{array}{l}\text { Nucleotide } \\
\text { sequence } \\
5^{\prime}-3\end{array}$ & $\begin{array}{l}\text { Annea- } \\
\text { ling } \\
\text { tempe- } \\
\text { rature } \\
\text { of } \\
\text { primer, } \\
\text { t }^{\circ} \mathrm{C}\end{array}$ & $\begin{array}{l}\text { Total } \\
\text { num-ber } \\
\text { of bands }\end{array}$ & $\begin{array}{l}\text { Number } \\
\text { of } \\
\text { poly- } \\
\text { morphic } \\
\text { bands }\end{array}$ & $\begin{array}{l}\text { Percen-tage } \\
\text { of } \\
\text { polymor- } \\
\text { phic } \\
\text { bands }\end{array}$ & $\begin{array}{l}\text { Size of DNA } \\
\text { fragments, bp }\end{array}$ \\
\hline 17899B & $(\mathrm{CA})_{6} \mathrm{GG}$ & 40 & 15 & 15 & 100 & $\sim 550-1400$ \\
\hline $\mathrm{HB} 12$ & $(\mathrm{CAC})_{3} \mathrm{GC}$ & 51 & 25 & 24 & 96 & $\sim 300-1700$ \\
\hline $\mathrm{M} 2$ & $(\mathrm{AC})_{8} \mathrm{Y}^{*} \mathrm{G}$ & 56 & 29 & 28 & 96,6 & $\sim 300-1250$ \\
\hline $\mathrm{M} 11$ & $(\mathrm{CA})_{6} \mathrm{R}^{* *}$ & 51 & 25 & 23 & 92 & $\sim 300-1100$ \\
\hline $\mathrm{UBC}-808$ & $(\mathrm{AG})_{8} \mathrm{C}$ & 60 & 25 & 23 & 92 & $\sim 700-2000$ \\
\hline
\end{tabular}

$* \mathrm{Y}=\mathrm{C}$ or $\mathrm{T} ; * * \mathrm{R}=\mathrm{G}$ or $\mathrm{A}$

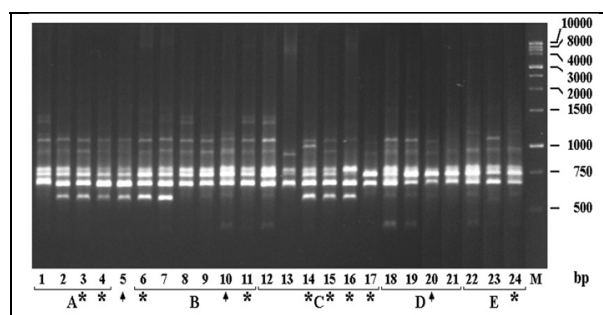

1. 7899B

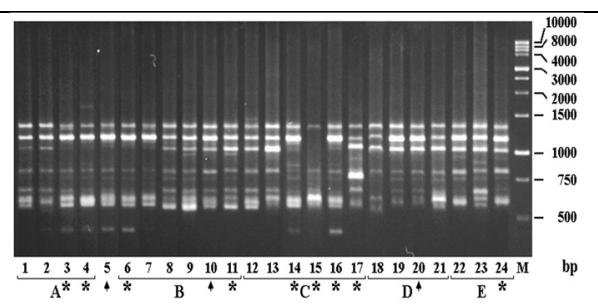

2. HB12 


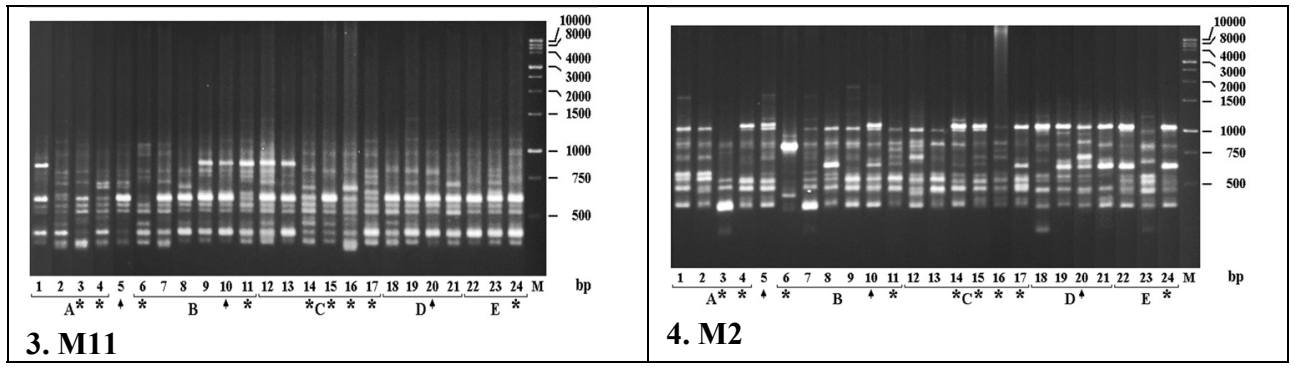

Fig.1. ISSR-variability and specificity of biotypes from different geographic regions (marked by letters) when using primers 17899B, HB12, M11, M2 (arranged by increasing variability). Accessions of taxa which formally do not belong to E. caninus marked by asterisks. Arrows indicate the hybrid specimens. Numbers of specimens are given according to Table 1. bp - scale of DNA fragments sizes (bp).

The consensus dendrogram was built according to data of ISSR-markers polymorphism by unweighted pair group method with arithmetic mean (UPGMA) (Fig. 2).

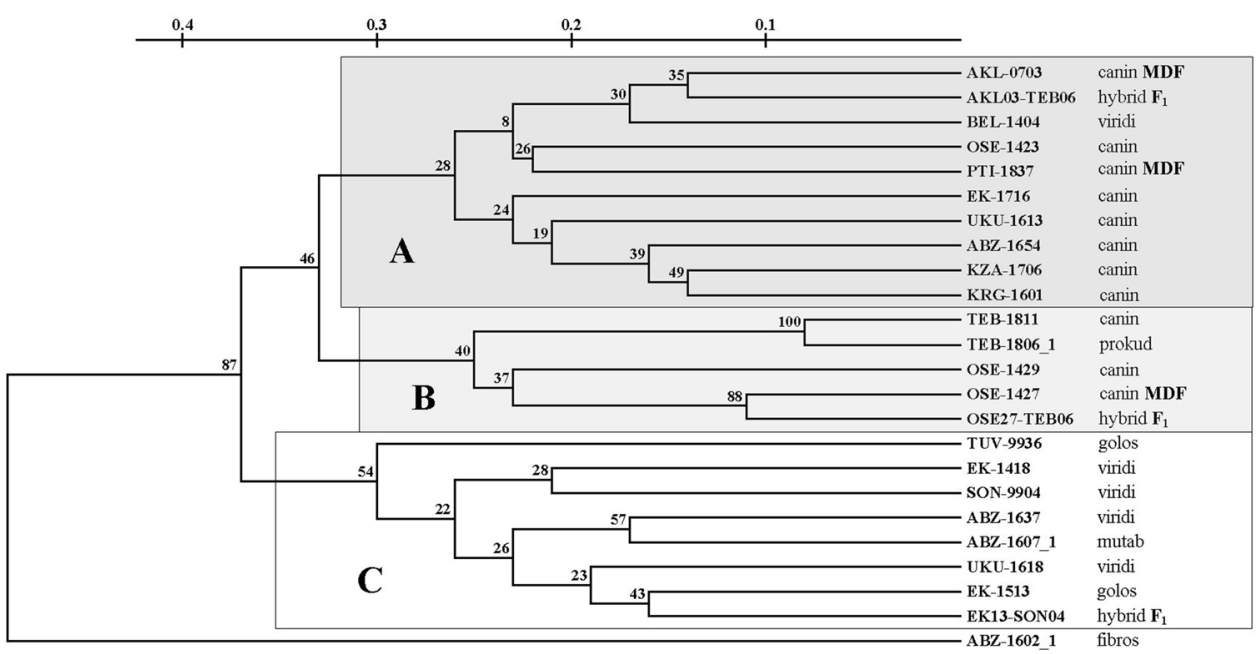

Fig.2. Consensus UPGMA dendrogram, built on the basis of spectra when using 5 ISSR-primers in taxa being morphologically close to E. caninus. Scale shows levels of differences.

According to species affiliation, in addition to E. caninus, the E. mutabilis ABZ-1607 and E. fibrosus ABZ-1602 should be considered the most valid accessions, because we referred all other accessions to doubtful species by formal traits in terms of microevolutional isolation and taxonomical independence. At the same time, E. fibrosus accession as expected showed the largest difference from all taxa, phylogenetically close to E. caninus. Results have shown that different accessions of taxa, morphologically close to typical material of E. caninus, have formed a common cluster $\mathbf{C}$ and separated from two other clusters with high bootstrap support value. Cluster A-B combines two clades with accessions, predominantly referred to E. caninus. Meanwhile clade B comprises three Caucasian E. caninus accessions with E. prokudinii. It is notable, that dendrograms, built on different ISSR-primers separately, showed slightly differing levels of genetic relationships. Hybrid plants, analyzed in three cross-combinations, have shown more close location to maternal specimens on consensus dendrogram. Along with this, the origin of two bright amplicons in hybrid E. caninus MDF OSE-1427 $\times$ E. prokudinii TEB-1806 (20) 
when using M2 primer remains unclear. We can suppose partial heterozygosity of paternal TEB-1806 genotype.

Nevertheless, the main conclusion is that all studied taxa represent complexes of specimens, phylogenetically connected with species radical E. caninus. In particular, the assumption was confirmed that $E$. viridiglumis as a species have polyphyletic origin in the frames of $E$. caninus microevolution with participation of ancestral or modern genotypes of closely related E. mutabilis species, as we supposed earlier [8]. Concerning Caucasian $E$. prokudinii species, the accession TEB-1806, identified by us, does not differ morphologically from Ural and Siberian accessions of E. viridiglumis.

This work was supported by the state project "Estimation of the morphogenetic potential of the North Asian plant population by experimental methods" (state registration number: AAAA-A17117012610051-5) for the Central Siberian Botanical Garden (CSBG) SB RAS, with partial financial support of the Russian Foundation for Basic Research (project No. 18-04-01030). Materials of the bioresource scientific collection of the CSBG SB RAS "Collections of living plants in open and closed ground", USU No. 440534 were used.

\section{References}

1. N.N. Tzvelev, N.S. Probatova, Grasses of Russia, (2019) (in Russian)

2. S.A. Nevsky, Flora of USSR, 2, 590-728 (1934) (in Russian)

3. R.M. Seredin, Novit. Syst. Pl. Vasc., 55-57 (1965) (in Russian)

4. N.N. Tzvelev, Novit. Syst. Pl. Vasc., 8, 57-83 (1971) (in Russian)

5. N.N. Tzvelev, Novit. Syst. Pl. Vasc., 10, 19-60 (1973) (in Russian)

6. Ju.A. Kotukhov, Turczaninowia, 7, 8-10 (2004) (in Russian)

7. E.V. Kobozeva, M.V. Emtseva, S.V. Asbaganov, A.V. Agafonov, Plant life of Asian Russia, 3, 43-50 (2017) (in Russian)

8. A.V. Agafonov, Rus. J. Genetics, 40, 1229-1238 (2004) 